\title{
The Effect of White Tea on the Increment of Smokers' Oxidative Status
}

\author{
Rosyanne Kushargina $^{\# 1}$, Rimbawan ${ }^{\# 2}$, Budi Setiawan ${ }^{\# 3}$ \\ \# Department of Public Nutrition, Bogor Agricultural University, Bogor 16680, Indonesia \\ E-mail: ${ }^{1}$ rosyannekushargina@gmail.com, ${ }^{2}$ rimbawan62@yahoo.com, ${ }^{3}$ bsetiawan.ipb@gmail.com
}

\begin{abstract}
Smokers are at high risk of oxidative stress. Many previous studies proved that tea is a source of antioxidants which might reduce oxidative stress. White tea is known to have the highest antioxidant capacity compared to other kinds of tea. Yet there was no sufficient evidence regarding the effect of white tea, especially against oxidative stress on smokers. This study was aimed to analyze the effect of white tea on oxidative status of smokers, using a pre-post experimental design. Nine medium smokers (11-21 cig/day) aged 30-45 years were instructed to drink $200 \mathrm{ml}$ white tea three times a day for 4 weeks. Total Antioxidant Capacity (TAC) of blood serum was measured 3 times. The first at baseline, the second after four weeks intervention, and the third 2 weeks after intervention period. The level of TAC significantly increased from $1,17 \mathrm{~m} \mathrm{~mol} / \mathrm{L}$ to $1,42 \mathrm{~m} \mathrm{~mol} / \mathrm{L}$ after 4 weeks intervention $(P=0.000)$. The increase in the TAC was only temporary, TAC significantly decreased from $1.42 \mathrm{~m} \mathrm{~mol} / \mathrm{L}$ to $1.18 \mathrm{~m}$ mol/L 2 weeks after the intervention $(P=0.000)$. These results prove that drinking $200 \mathrm{ml}$ of white tea 3 times a day for 4 weeks has a significant benefit on the oxidative status of smokers, although temporary. Smokers are advised to consume white tea continuously for to sustain these positive effects.
\end{abstract}

Keywords - white tea; medium smokers; oxidative status; total antioxidant capacity.

\section{INTRODUCTION}

Long-term and short-term smoking significantly increased oxidative stress [1], [2]. The Total Antioxidant Capacity (TAC) of smokers is significantly lower than non-smokers $(p<0.05)$ [3]. This increase was due to the effect of nicotine. The negative effects have not been able to reduce smoking activity. The number of smokers has risen continually. The prevalence of male population aged over 10 years who smoke every day in 2007 was $23.7 \%$ [4]. This number increased again in 2013 to $29.8 \%$ [5]. That was also followed by the increasing of average of smoked cigarettes. The data of the National Basic Health Research from the Indonesian Ministry of Health showed that the number increased from 10 cigarettes/day in 2010 [6] to 12.3 cigarettes /day in 2013 [5].

Many previous studies proved that tea is a capable source of antioxidants which might reduce oxidative stress [7]-[11]. Nowadays, flavour of white tea is more accepted in Europe than the green tea [12]. The potential effect of tea is caused by catechin content [13]. White tea is known to have the highest antioxidant capacity compared to other kinds of tea [14]. Several studies that linked green tea with smokers have been done. Asian populations who consumed green tea 3 cups/day have lower oxidative damage [7]. Intervention of green tea as a beverage has a positive effect on smokers after 2 weeks [15]. Yet there was no sufficient evidence regarding the effect of white tea, especially against oxidative stress on smokers. This study was aimed to analyze the effect of white tea on oxidative status of smokers.

\section{MATERIAL AND METHODS}

\section{A. Human subjects}

The study was conducted in January - February 2015 in Bogor, Indonesia. This study used 9 medium smokers (11-21 cig/day), aged 30-45 years, and assigned as employees of the Rubber Research Center of Bogor. Potential volunteers were excluded after initial screening if they reported the use of any medication or dietary supplements. Further exclusion criteria consisted of consuming alcohol, disliking tea, and drinking regular coffee more than 1 cup/day. This study has been approved by the Ethical Committee of the Faculty of Medicine, the University of Indonesia. Written informed consent was obtained from every volunteer.

\section{B. Experimental Design}

This study used a pre-post experimental design. Each subject took $200 \mathrm{ml}$ of white tea three times a day (08:00, 
12:00, and 16:00) for four weeks from Monday to Friday. During the study, subjects were instructed to avoid drinking other tea besides white tea that is used in the intervention; subjects' daily diet and lifestyle were kept normally. Food consumption at pre and during intervention were collected with 24-recall method using questioner. Blood specimens were taken three times; the first at baseline, the second after four weeks intervention, and the third at 2 weeks after 4 weeks intervention period. The serum blood for the total antioxidant capacity (TAC) measurement of all subjects were taken after a 12-h fast to rule out the acute effects of white tea intake.

\section{Preparation of Tea}

White tea infusions were prepared with commercially available dried tea leaves (Excellent White Tea Gamboeng) from the Research Centers of Tea and Kina Gamboeng, West Java. The white tea weighed $2 \mathrm{~g}$ was dipped into 200 $\mathrm{ml}$ boiled water $\left(95^{\circ} \mathrm{C}\right)$ for $9 \mathrm{~min}$ [16]. Every cup of tea was prepared by researcher on the day of intervention (Monday to Friday). It was consumed with no milk or sugar added.

\section{TAC in Plasma}

TAC analyzed in commercial laboratory using Trolox Equivalent Antioxidant Capacity (TEAC) with TAC kit (Randox Laboratories Ltd, Crumlin, UK). The assay principle is as follows: 2,20-azino-di-2-ethyl-benzthiazoline sulphonate (ABTS) is incubated with a peroxidase (metmyoglobin) and $\mathrm{H}_{2} \mathrm{O}_{2}$ to produce the radical cation ABTS $^{+}$. This has a relatively stable blue-green colour which is measured at $600 \mathrm{~nm}$. Antioxidants in the added sample cause suppression of this colour production to a degree proportional to their concentration. The assay was calibrated against an $a$-tocopherol analogue (Trolox) and the results were expressed as mmol/L of Trolox activity.

\section{E. Statistics}

We compared the TAC at baseline, after four weeks intervention, and the third 2 weeks after 4 weeks intervention period. The effects of white tea on TAC level were analysed statistically using paired sample t-test. Food consumption at pre and during intervention was collected using 24-recall method. These data were analysed statistically using paired sample t-test. Results are expressed as mean; significance was set at $\mathrm{P}<0.05$.

\section{RESULT AND DISCUSSION}

There were no side effects reported. Subjects had a mean of 34 years old and started smoking at 17 years old. A lot of habit of smoking started in the productive age (15-64 years) [17]. In Indonesia, 70\% of smokers started smoking before 19 years old [18].

Subject consumption (Table 1) was also collected before and during the intervention. This is to ensure there is no change in the consumption of the subject as it may affect the validation of the study results. Observed nutrition includes vitamins (vitamin A, folate, vitamin B12, vitamin C, vitamin E) and minerals (Fe and Zink) which may affect the level of TAC in the body [15], [19]-[23].
TABLE I

SubJect CONSUMPTION OF PRE AND DURING INTERVENTION PERIOD*

\begin{tabular}{|l|r|r|c|}
\hline \multirow{2}{*}{ Nutrients } & \multicolumn{3}{|c|}{ Mean } \\
\cline { 2 - 4 } & $\begin{array}{c}\text { Pre } \\
\text { intervention }\end{array}$ & $\begin{array}{c}\text { During } \\
\text { Intervention }\end{array}$ & P \\
\hline Vitamin A $(\mu \mathrm{g})$ & 288,41 & 285,40 & $0,730^{*}$ \\
\hline Vitamin B12 $(\mu \mathrm{g})$ & 2,55 & 2,56 & $0,289^{*}$ \\
\hline Folat $(\mu \mathrm{g})$ & 232,14 & 232,52 & $0,985^{*}$ \\
\hline Vitamin C $(\mathrm{mg})$ & 64,59 & 65,18 & $0,256^{*}$ \\
\hline Vitamin E $(\mathrm{mg})$ & 10,70 & 10,54 & $0,384^{*}$ \\
\hline Fe $(\mathrm{mg})$ & 7,92 & 7,90 & $1,000^{*}$ \\
\hline $\mathrm{Zn}(\mathrm{mg})$ & 8,30 & 8,28 & $0,516^{*}$ \\
\hline
\end{tabular}

" paired sample t-test $(\mathrm{p}>0.05)$ pre and during intervention period

There were no differences in the consumption of subjects before and during the intervention $(\mathrm{p}>0.05)$. So that can be ascertained that the changes in TAC levels were resulted from the given intervention.

Smokers are at high risk of oxidative stress. Smoking significantly decreases the oxidative status [2], so the smokers require high antioxidants [15]. Previous studies proved that smokers had a serum TAC significantly ( $p$ $<0.05$ ) lower than non-smokers [24], [25]. Subjects in this study had an average lower TAC which was only 1.17 $\mathrm{mmol} / \mathrm{L}$ at baseline (TAC_1; Fig.1). A TAC is said to be normal if the value is between 1.23 to $2.00 \mathrm{~m} \mathrm{~mol} / \mathrm{L}$.

Smoking is not healthy for the body because of many dangerous compounds in cigarette, poisonous chemical element, including nicotine. Nicotine can damage heart and blood circulation. Nicotine concentration is usually around $5 \%$ per 100 grams of tobacco. A cigarette typically contains 8-20 $\mathrm{mg}$ of nicotine depending on the type and brand of cigarette. Every cigarette that is smoked, the body will absorb $1 \mathrm{mg}$ nicotine. About 4-6 mg of nicotine per day can make an adult addicted [26].

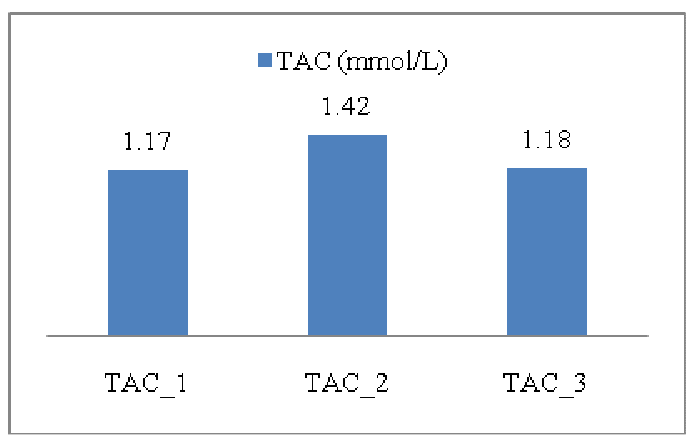

TAC_1: TAC at baseline; TAC_2: TAC after four weeks intervention; TAC_3: TAC at 2 weeks after intervention period

Fig. 1 Changes trend of TAC in subjects

The level of TAC significantly increased from 1.17 $\mathrm{mmol} / \mathrm{L}$ to $1.42 \mathrm{mmol} / \mathrm{L}$ after 4 weeks intervention $(\mathrm{P}=0.000)$ (Fig. 2). The increase in the TAC was only temporary, TAC significantly decreased from $1.42 \mathrm{~m} \mathrm{~mol} / \mathrm{L}$ to $1.18 \mathrm{~m} \mathrm{~mol} / \mathrm{L} 2$ weeks after the intervention $(\mathrm{P}=0.000)$. The results of this study showed that subjects will still have a low oxidative status if they continue their smoking habit. 
Chakraborty [27] shows that the antioxidants of tea can repair $50 \%$ of cell damages caused by cigarette smoke. Epigallocatechin 3-gallate (EGCG) is more effective in lowering oxidative stress compared with epicatechin (EC), epicatechin gallate (ECG), and epigallocatechin (EGC) [28]. EGCG is the largest component of tea catechins. Reference [29] suggests that EGCG is the final catechin (C) derivate and contains gallo and gallat which are more stable. This makes EGCG most prominent among the other types of catechins in tea. Based on the antioxidant activity, EGCG had the highest activity (EGCG> EGC> ECG> EC>C). EGCG activity accounted for $32 \%$ of the antioxidant potential of tea [30]. The increase in the subject TAC was due to the antioxidant contents of white tea. White tea contains antioxidants, especially EGCG, greater than green tea [13]. White tea is known to have particularly EGCG polyphenol content, which is the highest among all kinds of tea because of two factors: the minimum processing after harvest [31] and because it is made from peko [32]. Catechin content of peko is the highest, $26.5 \%$, compared to the other parts of the tea plant [32]. Long and complex processing of the tea leaves will reduce the content of catechin [31]. Different process after the tea leaves are picked will lead to differences in the content of polyphenols in tea. Longer fermentation lowered the catechin content and improved the content and tearubigin tea flavin. White tea processing only contains draining process in a minimal amount of time. This caused catechin in white tea to be higher than any other types of tea.

\section{CONCLUSIONS}

The increase in TAC is significant $(p=0.000)$ after four weeks intervention of white tea. This increase was only temporary, TAC decreased significantly $(\mathrm{p}=0.000) 2$ weeks after intervention period. It appears that white tea can reduce oxidative stress caused by smoking. Smokers are advised to consume white tea continuously to sustain these positive effects.

\section{ACKNOWLEDGMENT}

We would like to thank the Chairman of the Rubber Research Center of Bogor

\section{REFERENCES}

[1] H. Diken, K. Mustafa, T. Cemil, D. Basra, B. Yuksel, and S. Abbdurrahman, "Effect of cigarette smoking on blood antioxidant status in short term and long term smokers," Turk J Med Sci, Vol. 31, pp. 533-557, 2000.

[2] G. Block, M. Dietrich, E.P. Norkus, J.D. Morrow, M. Hudes, B. Caan, and L. Packer, "Factor assosiated with oxidative stress in human population," American Journal of Epidemiology 156(3), 2002.

[3] I. Onyesom, E. Osioma, and O.K. Ighodayenowho, "Serum antioxidant capacity of some nigerian cigarette smokers,". JPBM, Vol. 18(14), pp. 1-2, 2012.

[4] Ministry of Health, The data of the National Basic Health Research from Ministry of Health 2007, Indonesian Ministry of Health, 2008.

[5] Ministry of Health, The data of the National Basic Health Research from Ministry of Health 2010, Indonesian Ministry of Health, 2010.

[6] Ministry of Health, The data of the National Basic Health Research from Ministry of Health 2013, Indonesian Ministry of Health, 2013.

[7] P. Lee, Y.H. Kim, M.H. Kang, C. Roberts, J.S. Shim, and J.K. Roh, "Chemopreventive effect of green tea (camellia sinensis) against cigarette smoke-induced mutations (SCE) in Human," J Cell Biochem Suppl, Vol. 27, pp. 68-75, 1997.
[8] C. Coimbra, R. Elisabeth, P. Petronila, R. Irene, R. Susana, and S.S Alice, "The effect of tea in oxidative stress," Clinical Nutrition, Vol. 25, pp. 790-796, 2006.

[9] N. Nagaya, H. Yamamoto, M. Uematsu, T. Itoh, K. Nakagawa et al., "Green tea reverses endothelial dysfunction in healthy smokers," Heart., Vol. 90, pp. 1485-1486, 2004.

[10] M. Serafini, J.A. Laranjinha, L. M. Almeida, and G. Maiani, "Inhibition of human LDL lipid peroxidation by phenol-rich beverages and their impact on plasma total antioxidant capacity in humans," J. Nutr. Biochem, Vol. 11, pp. 585-590, 2000.

[11] T. Murakami and K. Ohsato, "Dietary green tea intake preserves and improves arterial compliance and endothelial function," J. Am. Coll. Cardio, Vol. 41, pp.271, 2003.

[12] M.P. Almajano,R. Carbo, J. Jiménez, and M.H. Gordon, "Antioxidant and antimicrobial activities of tea infusions," Food Chemistry, Vol. 108(1), pp. 55-63, 2008.

[13] F. Firenzuoli, L. Gori, A. Crupi, and D. Neri, “ Flavonoids: risks or therapeutic opportunities," Recenti Progressi in Medicina, Vol. 95, pp. 345-351, 2004.

[14] Hilal and Engelhardt, "Characterisation of white tea - comparison to green and black tea," Journal of Consumer Protection and Food Safety, Vol. 2, pp. $414-421,2007$.

[15] G. Kelly, "The interaction of cigarette smoking and antioxidant part I: diet and caroteniods," Alternative Medicine Review, Vol. 7(5), 2002.

[16] D. Rohdiana, D.Z. Arief, and M. Soemantri, "(1-Diphenyl-2Picrylhydrazyl) free radical scavenging activity of white tea base on temprature and period of brewing," Jurnal Penelitian Teh dan Kina, Vol. 16(1), pp. 45-50, 2013.

[17] R. Sulaiman. (2014) Cigarettes, alcohol, and drugs gnaw productive population. [Online]. Available: http//:sman2byl.sch.id

[18] Adhayanti,"Correlation between knowledge of the health hazards of smoking to smoking behavior," Undergraduate Thesis, Brawijaya University, Malang, Indonesia, 2007.

[19] Y.Z. Dwifitri, "Identify the relationship of smoking habits in women with high levels of vitamin C and LDL cholesterol blood serum," Undergraduate Thesis, Bogor Agriculture University, Bogor , Indonesia, 1999.

[20] F. Bamonti, C. Novembrino, S. Ippolito, E. Sorezi , A. Ciani, S. Lonati, E. Scurati-Manzoni, and G. Cighetti, "Increased free malondialdehyde aondentration in smokers normalise with a mixed fruit and vegetable juice concentrate: a pilot study," Clin Chem Lab Med, Vol. 44(4), pp. 391-395, 2006.

[21] C. J. Piyathilake, M. Mourizio, R. Jean Hine, W.R. Ernest, and C.L. Krimdieck, "Local and systematic effect of cigarette smoking on folat and vitamin B 12,”. J. Clin. Nutr, Vol.60, pp. 559-566, 1994.

[22] S. K. Bashar and A.K. Mitra, "Effect of smoking on vitamin A. vitamin $\mathrm{E}$ and other trace elements in patients with cardiovascular disease in Bangladesh: a cross sectional study," Nutrition Journal, Vol. 3(18), 2004.

[23] K. Anbarasi, G. Vani, K. Balakrisna, and C.S. Devi, "Effect of bacoside A on brain antioxidant status in cigarette smoke exposed rats," Life Science, Vol. 78, pp. 1378-1384, 2006.

[24] I. Onyesom, E. Osioma, and O.K. Ighodayenowho, "Serum antioxidant capacity of some nigerian cigarette smokers.," JPBM, Vol. 18(14), pp.1-2, 2012.

[25] H. Kurku, M. Kacmaz, U. Kisa, O. Dogan, and O. Caglayan, "Acute and cronic impact of smoking on salivary and serum total antioxidant capacity." J Pak Med Assoc,Vol.65(2), pp. 164-169, 2015.

[26] M. Sitepoe, Usaha Mencegah Bahaya Merokok, 3nd, Jakarta: PT Gramedia Widiasarana Indonesia, 2000.

[27] A. Chakraborty, A. Gupta, A. K. Singh, and P. Patni, "Effect of oxidative phytochemicals on nicotine-stresssed UMNSAH/DF-1 cell line," J Tradit Complement Med. Vol. 4(2), pp. 126-131, 2014

[28] H. Wang, "Catechins: the essence of tea". FoodInfo-IFIS Publishing, 2002.

[29] T. Shimamura, W. Zho, and Z. Hu, "Mechanism of action and potential for use of tea catechine as an anti-infective," Anti-infective Agent in Medical Chemistry, Vol. 6(1), pp. 57-62, 2007.

[30] D. Rohdiana. Teh Ini Menyehatkan : Telaah Ilmiah Populer, Bandung: Penerbit Alfabeta, 2011.

[31] T. R. Dias, G. Tomás, N. F. Teixeira, M. G. Alves. P. F. Oliveira, and B. M. Silva, "White tea (camellia sinensis (1.)): antioxidant properties and beneficial health effects," International Journal of Food Science. Nutrition and Dietetics (IJFS), Vol. 2(101), 2013.

[32] L. Yunitasari, "Quality control of black tea processing units Plantation Tambi, PT. Plantation Tambi Wonosobo," Undergraduate Thesis, University of Surakarta, Surakarta, Indonesia, 2010. 